\title{
Determination of illegal colorants in grilled meats by liquid chromatography-tandem mass spectrometry
}

\author{
Doan Thu Huyen ${ }^{1^{*}}$, Pham Thi Thanh $\mathrm{Ha}^{1}$, Nguyen Quang $\mathrm{Ha}^{2}$, Luong Nguyen Thuy Duong ${ }^{2}$ \\ Trinh Viet $\mathrm{Van}^{2}$, Nguyen Thi Hong Ngoc ${ }^{3}$, Tran Cao Son ${ }^{3}$ \\ ${ }^{1}$ Hanoi University of Pharmacy, Hanoi, Vietnam \\ ${ }^{2}$ Nguyen Hue High School for Gifted Student, Hanoi, Vietnam \\ ${ }^{3}$ National Institute for Food Control, Hanoi, Vietnam
}

(Received: 02/11/2020; Accepted: 21/12/2020)

\section{Abstract}

An analytical method using liquid chromatography-tandem mass spectrometry (LCMS/MS) was validated for the simultaneous determination of three illegal colorants including chrysoidine G, para red, and pararosaniline in grilled meat. The meat samples were homogenized and extracted by QuEChERS, and analyzed by LC-MS/MS. Good linearity was obtained in a range of $30.0-1,000 \mu \mathrm{g} / \mathrm{L}, 5.0-1,000 \mu \mathrm{g} / \mathrm{L}$, and $0.5-1,000 \mu \mathrm{g} / \mathrm{L}$ for chrysoidine $\mathrm{G}$, para red, and pararosaniline, respectively. The repeatability and accuracy of the method were adequate with the recoveries ranged from $90 \%$ to $98 \%$ and RSD\% of 5.3 to $10.7 \%$ for three compounds. The procedure was applied for 49 samples of different types of grilled meat collected from six different areas in Hanoi. Chrysoidine G was detected in 19 samples. It is remarkable that among these positive samples, six samples were found negative on homogenized samples, and positive with chrysoidine selected sample with the more intensely colored surface part.

Keywords: Illegal colorants, grilled meat, liquid chromatography-tandem mass spectrometry, chrysoidine G, para red, pararosaniline.

\section{INTRODUCTION}

Food colour, which is natural or artificial, is added to food preparations in order to compensate for the colours destroyed by the harsh conditions applied during food processing or to increase their attractiveness. However, industrial colorants, which possess great features: cheap, easy to use, sustainable, are now widely sold in the market. The illegal use of industrial colorants in food can be harmful to human health, such as hyperactivity in children, allergy, and especially genetic mutations that are considered as a carcinogen. Therefore, in Vietnam, the Ministry of Health has issued Circular 24/2019/TT-BYT on the management and use of food additives. According to the Circular, only 51 colorants are allowed to be used as food additives [1]. Other synthetic pigments not included in this list, will not be allowed to be added to foods. Illegal use of unauthorized dyes was reported in Asian countries such as India [2], China [3], the Philippines [4], and also Viet Nam [5].

Grilled meat, fried meatballs, and sausages are favorite fast food for children, which are usually available in front of almost all schools in big cities in Vietnam. This kind of fast food is at high risk of illegal use of colorants. Chrysoidine G, para red, and pararosaniline are industrial dyes that can help create colour similar to that of natural meat (structure and colour presented 
in Table 1). These dyes are cheap and accessible to users, meanwhile, the grilled meat, sausage, or meatballs are usually sold at small shops/booths or mobile stores. These facts facilitate the high potential of the illegal use of these colorants in grilled meat and fried meatballs stores. On the other hand, these compounds are potentially harmful to human health. It was reported that chrysoidine could result in acute and chronic toxicity to mammal when taken by oral or skin route, or inhaled [6-7]. Although there is very limited data available, the U.K. FSA independent scientific experts have advised that para red could be a genotoxic carcinogen [8]. There is ample evidence that pararosaniline can be regarded as being able to cause cancer in humans based on experiments and other information [8]. Safety and hazard-related properties of the three colorants according to the GSH classification (GHS, the Globally Harmonized System of Classification and Labeling of Chemicals) were presented in Table 1.

Table 1. Structure, colour and properties of the investigated colorants

\begin{tabular}{|c|c|c|c|}
\hline Name & Chrysoidine G & Para Red & Pararosaniline \\
\hline \multicolumn{4}{|l|}{ Colour } \\
\hline Formula & $\cdot \mathrm{HCl}$ & & $\mathrm{HCl}$ \\
\hline & $\mathrm{C}_{12} \mathrm{H}_{13} \mathrm{ClN}_{4} \quad 248,71$ & $\mathrm{C}_{16} \mathrm{H}_{11} \mathrm{~N}_{3} \mathrm{O}_{3} 293.28$ & $\mathrm{C}_{19} \mathrm{H}_{18} \mathrm{~N}_{3} \mathrm{Cl} \quad 323.82$ \\
\hline Properties & Soluble in water, ethanol, aceton & Soluble in ethanol & Soluble in ethanol \\
\hline $\begin{array}{l}\text { Health } \\
\text { Effects }\end{array}$ & $\begin{array}{l}\text { Harmful if swallowed, causes skin } \\
\text { irritation, serious eye damage, } \\
\text { suspected genetic defects }\end{array}$ & $\begin{array}{l}\text { Causes skin irritation, serious } \\
\text { eye irritation, possible } \\
\text { respiratory irritation }\end{array}$ & May cause cancer \\
\hline
\end{tabular}

Researchers have been using LC-MS/MS for the simultaneous determination of para red, pararosaniline, and chrysoidine $G$, which are illegally used in various foods such as soft drinks [9], eggs [10], animal feeds [11], processed foods [12] and products made from chili [3]. Compare to these types of food, grilled meat is a much more complicated sample. Grilled meat or fried meatballs contain a high amount of fat, protein, and sugar, which can interfere with the performance and analytical equipment. Sample preparation, therefore, should be able to obtain a clean sample if LC-MS/MS is used. Furthermore, since the amounts of pigments in meat are small, a sample preparation with high extraction efficiency is required. In our previous study, an LC-MS/MS method was developed for the simultaneous determination of 16 pigments in food [5]. The pigments covered in the previous study included all three colorants of the present study, but for simpler samples, i.e., chili powder and dried beef. Moreover, para red, pararosaniline, and chrysoidin $\mathrm{G}$ were suspected and found as illegal colorants in food in Asian countries like China [11-12], India [2], and Japan [10]. This study focused on these three potential colorants with a similar color to natural meat, and the analytical method developed by our research group in [5] was validated on a new sample matrix, grilled meat (pork on the stick, illustrated in Figure 1). 


\section{MATERIALS AND METHODS}

\subsection{Chemicals and materials}

Reference standards of chrysoidine G (Lot. 675486, > 95\%), para red (Lot. MKBX8680V, $>$ 95\%), and pararosaniline (Lot. MKBT5119V, > 99\%) were obtained from Sigma - Aldrich (USA). Acetonitrile, formic acid, and other solvents were purchased from Merck (Germany), magnesium sulfate, sodium chloride, sodium acetate, and other solid reagents were purchased from Sigma - Aldrich (USA) while d-SPE clean-up reagents as GCB, PSA, and C10 were obtained from Agilent (USA).

Samples used for method validation was the grilled meat sample determined to be free of investigated colorants. Sample for method application included 49 samples of different types: grilled skewers of sliced pork, minced pork (meatballs), roasted duck, and sausage. An amount of around $100 \mathrm{~g}$ of each sample was bought from different areas around schools, hospitals, local markets, and busy residential places in six districts in Hanoi: Hoan Kiem, Dong Da, Tay Ho, Thanh Xuan, Cau Giay, and Ha Dong.

\subsection{Equipment}

The analysis was performed on LC-MS/MS system with UPLC 1290 system and triple quadrupole mass spectrometer 6460 with electron ionization source (ESI) from Agilent Technology (USA). Other types of equipment used in the experiments included analytical balance (Satorius, Germany), centrifuge (Satorius, Germany), vortex (Velp, Germany), shaker (GFL, Germany).

\subsection{Method}

In our previous study, an LC-MS/MS method was developed for the determination of 16 colorants including chrysoidine G, para red, and pararosaniline in chili powder and dried beef [5]. For the application in grilled meat, the method was validated on a new sample matrix, grilled pork skewer. Validation tests were conducted according to AOAC guidelines including selectivity, linearity, precision, recovery, limit of detection (LOD), and limit of quantitation (LOQ) [13]. The sample preparation procedure and analytical conditions for LC-MS/MS were described as follows.

\subsubsection{Sample preparation method}

At the time of collection (purchase), the meat was grounded (or minced by electric mincer), and homogenized thoroughly. An amount of $2 \mathrm{~g}$ of homogenized sample was accurately weighed into a $15 \mathrm{~mL}$ centrifuge tube, $2 \mathrm{~mL}$ of water and $8 \mathrm{~mL}$ of acetonitrile was added consecutively, each addition followed by 1 min vortexing, then the sample was horizontally shaken for 30 minutes. Next, a mixture of $4 \mathrm{~g}$ magnesium sulfate and $1 \mathrm{~g}$ sodium acetate was added into the sample, vigorously shaken, followed by refrigerated centrifuging at 6,000 rpm for $5 \mathrm{~min}$. Then, $1 \mathrm{~mL}$ of solution was transferred into a d-SPE tube containing $0.12 \mathrm{MgSO}_{4}$, $0.05 \mathrm{~g}$ PSA, and $0.05 \mathrm{~g} \mathrm{C18}$, vortexed for $1 \mathrm{~min}$, centrifuged at 12,000 rpm, filtered through a sample filter of $0.22 \mathrm{~nm}$, and was injected into the LC-MS/MS system.

\subsubsection{LC-MS/MS method}

An Acquity C18 column $(2.1 \times 50 \mathrm{~mm}, 1.7 \mu \mathrm{m})$ was used. The mobile phase system consisted of solution A ( $0.1 \%$ formic acid aqueous solution) and B (ACN). A gradient program was used 
for elution: $80 \% \mathrm{~B}$ at $1.0-8.0 \mathrm{~min}, 30 \% \mathrm{~B}$ at $8.0-12.0 \mathrm{~min}, 10 \% \mathrm{~B}$ at $12.1-15.0 \mathrm{~min}, 80 \% \mathrm{~B}$ at 15.1 - B at $1.0-8.0 \mathrm{~min}, 30 \% \mathrm{~B}$ at $8.0-12.0 \mathrm{~min}, 10 \% \mathrm{~B}$ at $12.1-15.0 \mathrm{~min}, 80 \% \mathrm{~B}$ at $15.1-20.0 \mathrm{~min}$. The flow rate was set at $0.4 \mathrm{~mL} / \mathrm{min}$. Mass spectrometry conditions and mass fragments are shown in Table 2, example of mass spectrum of pararosaniline was presented in Figure 1.

Table 2. MS/MS conditions

\begin{tabular}{lccccc}
\hline \multicolumn{1}{c}{ Analyte } & $\begin{array}{c}\text { Precursor ion } \\
(\boldsymbol{m} / \boldsymbol{z})\end{array}$ & $\begin{array}{c}\text { Production } \\
(\boldsymbol{m} / \boldsymbol{z})\end{array}$ & $\boldsymbol{C E}(\boldsymbol{e V})$ & $\begin{array}{c}\text { Ion ratio } \\
(\%)\end{array}$ & $\begin{array}{c}\boldsymbol{t}_{\boldsymbol{R}} \\
(\mathbf{m i n})\end{array}$ \\
\hline Chrysoidine $\boldsymbol{G}$ & 213.2 & $196,1 / 121^{\star}$ & $20 / 20$ & 8.5 & 0.68 \\
Para Red & 294.1 & $156 / 128^{\star}$ & $14 / 30$ & 80 & 0.82 \\
Pararosaniline & 288.2 & $195^{*} / 151$ & $30 / 58$ & 14 & 9.49 \\
\hline
\end{tabular}

* Quantification ion

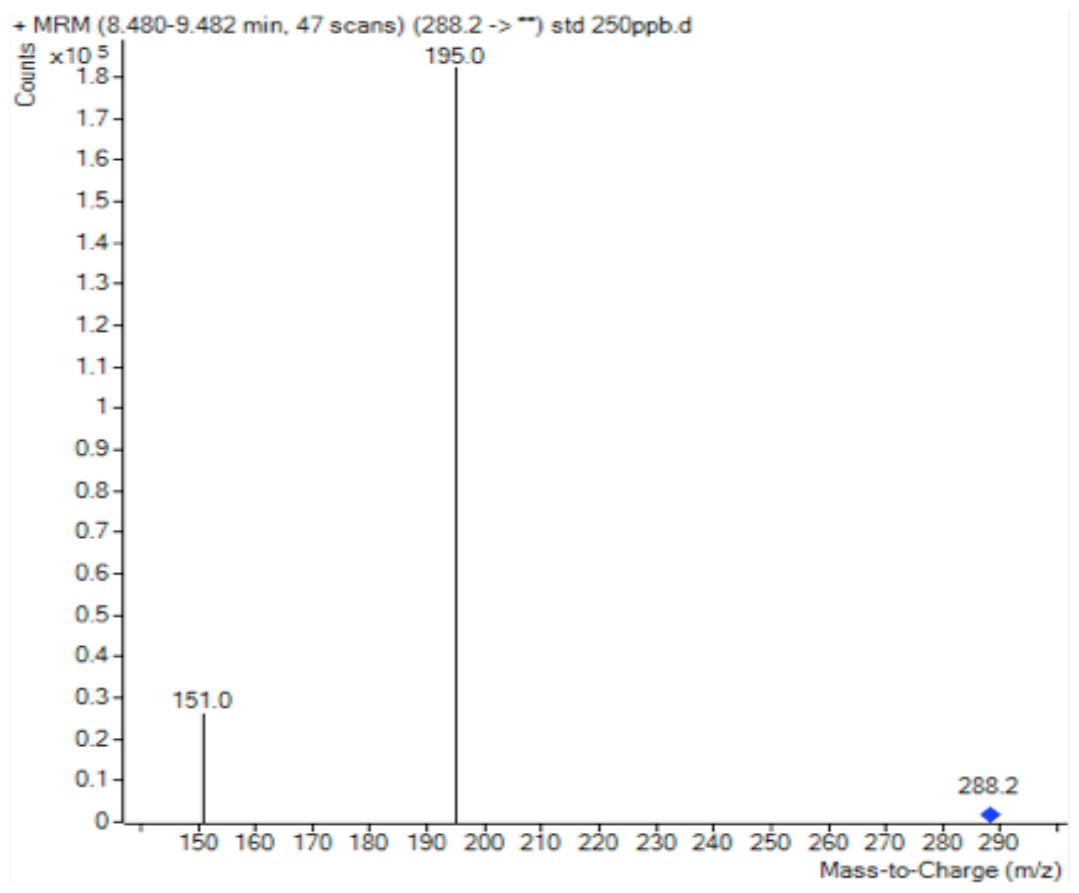

Figure 1. Mass spectrum of pararosaniline

\section{RESULTS AND DISCUSSION}

\subsection{Method validation}

\subsubsection{Selectivity}

Each analyte was identified by precursor ion and two product ions, with IP of four (in compliance with 657/2002/EC). The difference in retention time of the analytes in standard solution from those in spiked sample solution was $0.20 \%, 0.06 \%$, and $0.50 \%$ for chrysoidine $G$, para red, and pararosaniline, respectively, not more than 5\% (in compliance with 657/2002/EC). The chromatograms of blank and standards were presented in Figure 2. 
Chrysoidine G

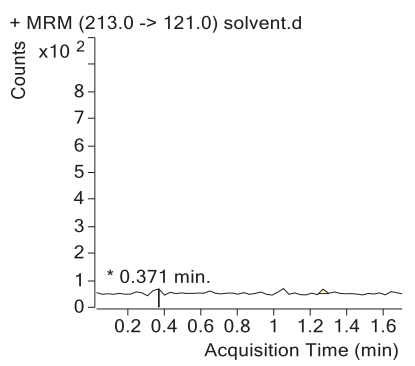

Standard

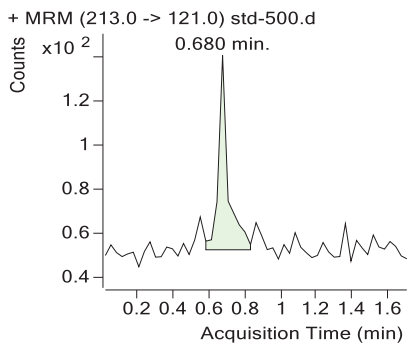

Para red
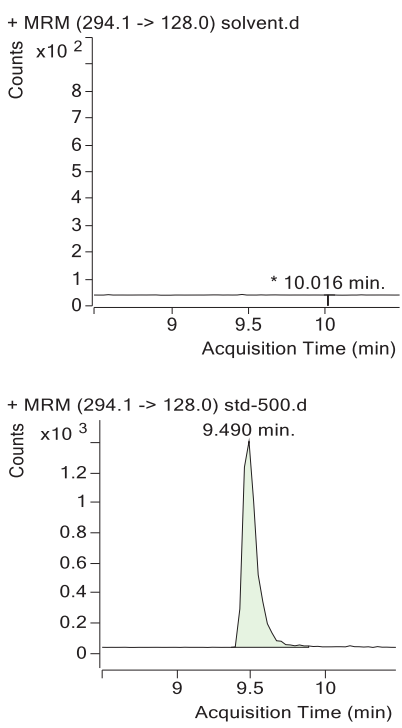

Pararosaniline

+ MRM (288.2 -> 195.0) solvent.d

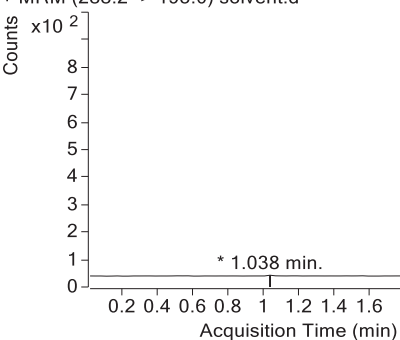

+ MRM (288.2 -> 195.0) std-500.d

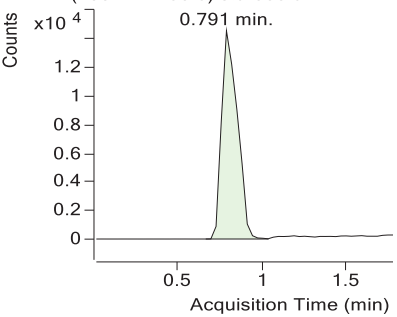

Figure 2. Chromatograms of blank and standards in selectivity test

\subsubsection{LOD and LOQ}

The mixed standard solutions were diluted and analyzed. LOD and LOQ were determined at a concentration in which the signal-to-noise ratio was equal to 3 (for LOD) and 10 (for LOQ). The obtained LOD and LOQ were 10 and $30 \mathrm{ng} / \mathrm{mL}$ for chrysoidine $\mathrm{G}, 1$ and $5 \mathrm{ng} / \mathrm{mL}$ for para red, 0.2 and $0.5 \mathrm{ng} / \mathrm{mL}$ for pararosaniline. The LOQ equivalent to the colorant content in the sample was $150 \mu \mathrm{g} / \mathrm{kg}$ for chrysoidine $\mathrm{G}, 25 \mu \mathrm{g} / \mathrm{kg}$ for para red, $2.5 \mu \mathrm{g} / \mathrm{kg}$ for pararosaniline.

\subsubsection{Linearity}

Linearity was studied by analyzing mixed standard solutions at several concentrations ranging from LOQ concentration of the analyte to $1000 \mu \mathrm{g} / \mathrm{L}$ with the following concentrations: $0.5,1.0,5.0,10,50,100,250,500$, and $1,000 \mathrm{ng} / \mathrm{mL}$. The linearity range, calibration curve, and correlation coefficient were presented in Table 3.

\subsubsection{Recovery and precision}

Recovery and precision were investigated on spiked samples at three levels to obtain the final concentration in the extract of 50, 250, and $500 \mathrm{ng} / \mathrm{mL}$. Six replicates were tested for each concentration. The results were presented in Table 3.

Table 3. Results of method validation

\begin{tabular}{cccc}
\hline & Chrysoidine $\boldsymbol{G}$ & Para red & Pararosaniline \\
\hline Linearity range & $30-1,000 \mathrm{ng} / \mathrm{mL}$ & $5.0-1,000 \mathrm{ng} / \mathrm{mL}$ & $0.5-1,000 \mathrm{ng} / \mathrm{mL}$ \\
Equation & $\mathrm{y}=9.658 \mathrm{x}+65.8$ & $\mathrm{y}=18.04 \mathrm{x}+163.2$ & $\mathrm{y}=344.2 \mathrm{x}+2258$ \\
Correlation & $\mathrm{R}^{2}=0.9987$ & $\mathrm{R}^{2}=0.9996$ & $\mathrm{R}^{2}=0.9997$ \\
\hline Recovery & $90-96 \%$ & $91-98 \%$ & $94-97 \%$ \\
\hline Precision & $5.3-10.7 \%$ & $6.9-10.1 \%$ & $5.9-10.4 \%$ \\
\hline
\end{tabular}


The results showed that the developed method satisfied with the criteria of AOAC guidelines [13], and was applicable for the determination of the three colorants in grilled meat samples.

\subsection{Method application}

The procedure, after being re-validated on grilled meat sample, was applied for the analysis of 49 samples, each sample was prepared in duplicate. Types of grilled meat and location where the sample was collected were briefly reported in Figure 3.

Different types of grilled meat were collected, including grilled pork skewers, meatball skewers, grilled pork in a whole piece, doner kebab meat, and sausage. Samples were purchased from six different districts including Hoan Kiem, Dong Da, Thanh Xuan, Ha Dong, Cau Giay, and Tay Ho. The shops were chosen with the same criteria as the first set of samples: small street-side booths, without shop brand names, in crowded areas as schools, universities, open markets, and busy residential areas. Due to the fact that more variety of sample types were included, and for some samples that the colorant was only on the thin surface of a big piece of meat (that was visually recognizable), the sample preparation procedure was slightly adapted. Instead of preparation in duplicate, we decided to do two different weighings: first weighing as the homogenized sample (set 1 in Table 4), and second weighing as the selected sample, where the more intensely colored part was selected (set 2 in Table 4).

\section{Types/location of samples}

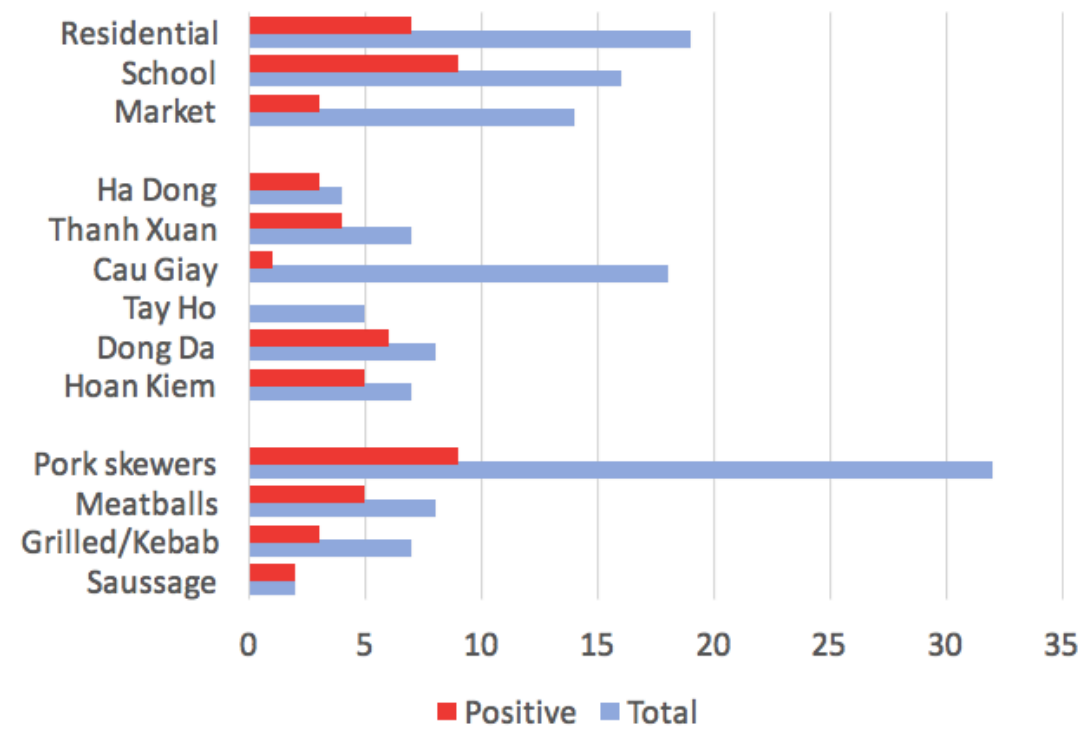

Figure 3. Number of positive samples and the total number of investigated samples for each type of meat, type of location, and district

Among 49 samples, 19 samples were detected with chrysoidine $G$ at different concentrations (Table 4), para red and pararosaniline was not detected in any study samples. One special fact was noticed, that the number of samples detected with illegal colorants in the second weighing was higher than the first weighing, and in some cases, content of colorant was also higher in the second weighing. Figure 4 presented chromatograms of some typical samples of results obtained with two weighings. 
a)
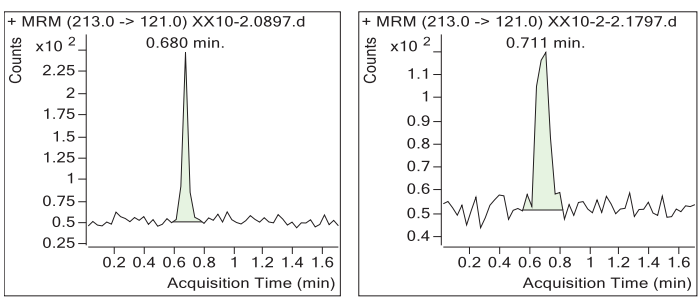

c)

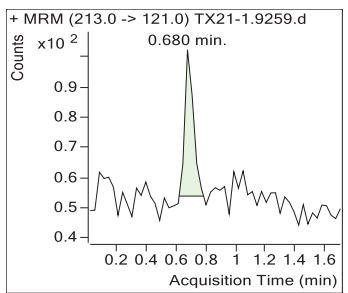

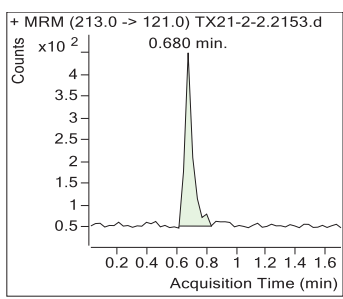

b)
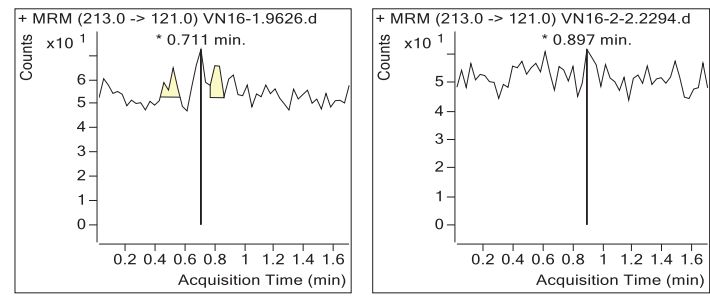

d)

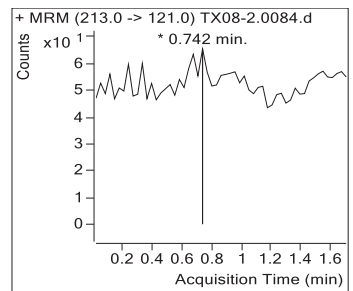

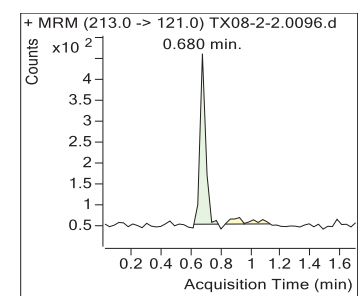

Figure 4. Typical results of a) same positive results; b) same negative results; c) both positive results with 10 times difference in concentration; d) one negative and one positive result

Table 4. Description and results from the investigated samples

\begin{tabular}{|c|c|c|c|c|c|c|c|c|c|}
\hline \multirow{2}{*}{$\begin{array}{l}\text { Sample } \\
\text { code }\end{array}$} & \multirow{2}{*}{$\begin{array}{c}\text { Type of grilled } \\
\text { meat }\end{array}$} & \multirow{2}{*}{ District } & \multirow{2}{*}{ Location } & \multicolumn{2}{|c|}{$\begin{array}{c}\text { Chrysoidine } \\
G(\mu g / k g)\end{array}$} & \multicolumn{2}{|c|}{$\begin{array}{c}\text { Para Red } \\
(\mu \mathrm{g} / \mathrm{kg})\end{array}$} & \multicolumn{2}{|c|}{$\begin{array}{c}\text { Pararosaniline } \\
(\mu \mathrm{g} / \mathrm{kg})\end{array}$} \\
\hline & & & & Set 1 & Set 2 & Set 1 & Set 2 & Set 1 & Set 2 \\
\hline TV01 & Meatball skewers & Thanh Xuan & $\begin{array}{l}\text { School/ } \\
\text { university }\end{array}$ & $(-)$ & 361 & $(-)$ & $(-)$ & $(-)$ & $(-)$ \\
\hline TV02 & Meatball skewers & Thanh Xuan & $\begin{array}{l}\text { School/ } \\
\text { university }\end{array}$ & $(-)$ & 4,183 & $(-)$ & $(-)$ & $(-)$ & $(-)$ \\
\hline TV03 & Meatball skewers & Ha Dong & $\begin{array}{l}\text { School/ } \\
\text { university }\end{array}$ & $(+)$ & 2,180 & $(-)$ & $(-)$ & $(-)$ & $(-)$ \\
\hline TV04 & Meatball skewers & Ha Dong & $\begin{array}{l}\text { School/ } \\
\text { university }\end{array}$ & $(+)$ & 1,288 & $(-)$ & $(-)$ & $(-)$ & $(-)$ \\
\hline TV05 & Meatball skewers & Hoan Kiem & $\begin{array}{l}\text { School/ } \\
\text { university }\end{array}$ & 661 & 1,965 & $(-)$ & $(-)$ & $(-)$ & $(-)$ \\
\hline TX06 & $\begin{array}{l}\text { Grilled pork } \\
\text { skewers }\end{array}$ & Hoan Kiem & $\begin{array}{l}\text { School/ } \\
\text { university }\end{array}$ & 2,566 & 3,555 & $(-)$ & $(-)$ & $(-)$ & $(-)$ \\
\hline XX07 & Sausages & Hoan Kiem & $\begin{array}{l}\text { Residential } \\
\text { area }\end{array}$ & 1,084 & 3,428 & $(-)$ & $(-)$ & $(-)$ & $(-)$ \\
\hline TN08 & $\begin{array}{l}\text { Grilled pork } \\
\text { whole piece }\end{array}$ & Hoan Kiem & $\begin{array}{l}\text { Residential } \\
\text { area }\end{array}$ & $(-)$ & 4,964 & $(-)$ & $(-)$ & $(-)$ & $(-)$ \\
\hline TX09 & $\begin{array}{l}\text { Grilled pork } \\
\text { skewers }\end{array}$ & Dong Da & Open market & 1,998 & 2,786 & $(-)$ & $(-)$ & $(-)$ & $(-)$ \\
\hline XX10 & Sausages & Dong Da & Open market & 2,251 & 1,743 & $(-)$ & $(-)$ & $(-)$ & $(-)$ \\
\hline TN11 & $\begin{array}{l}\text { Grilled pork } \\
\text { whole piece }\end{array}$ & Thanh Xuan & Open market & $(+)$ & 2,519 & $(-)$ & $(-)$ & $(-)$ & $(-)$ \\
\hline TN12 & $\begin{array}{l}\text { Grilled pork } \\
\text { whole piece }\end{array}$ & Dong Da & $\begin{array}{l}\text { Residential } \\
\text { area }\end{array}$ & 2,687 & 1,987 & $(-)$ & $(-)$ & $(-)$ & $(-)$ \\
\hline
\end{tabular}




\begin{tabular}{|c|c|c|c|c|c|c|c|c|c|}
\hline TX13 & $\begin{array}{l}\text { Grilled pork } \\
\text { skewers }\end{array}$ & Dong Da & $\begin{array}{l}\text { Residential } \\
\text { area }\end{array}$ & $(-)$ & 462 & $(-)$ & $(-)$ & $(-)$ & $(-)$ \\
\hline TX20 & $\begin{array}{l}\text { Grilled pork } \\
\text { skewers }\end{array}$ & Dong Da & $\begin{array}{l}\text { School/ } \\
\text { university }\end{array}$ & $(-)$ & 258 & $(-)$ & $(-)$ & $(-)$ & $(-)$ \\
\hline TX21 & $\begin{array}{l}\text { Grilled pork } \\
\text { skewers }\end{array}$ & Cau Giay & $\begin{array}{l}\text { School// } \\
\text { university }\end{array}$ & 634 & 6,036 & $(-)$ & $(-)$ & $(-)$ & $(-)$ \\
\hline TX26 & $\begin{array}{l}\text { Grilled pork } \\
\text { skewers }\end{array}$ & Hoan Kiem & $\begin{array}{l}\text { School// } \\
\text { university }\end{array}$ & 370 & 417 & $(-)$ & $(-)$ & $(-)$ & $(-)$ \\
\hline TX27 & $\begin{array}{l}\text { Grilled pork } \\
\text { skewers }\end{array}$ & Dong Da & $\begin{array}{l}\text { Residential } \\
\text { area }\end{array}$ & $(-)$ & $(+)$ & $(-)$ & $(-)$ & $(-)$ & $(-)$ \\
\hline TX28 & $\begin{array}{l}\text { Grilled pork } \\
\text { skewers }\end{array}$ & Thanh Xuan & $\begin{array}{l}\text { Residential } \\
\text { area }\end{array}$ & 1,804 & 4,352 & $(-)$ & $(-)$ & $(-)$ & $(-)$ \\
\hline TX29 & $\begin{array}{l}\text { Grilled pork } \\
\text { skewers }\end{array}$ & Ha Dong & $\begin{array}{l}\text { Residential } \\
\text { area }\end{array}$ & 3,645 & 2,965 & $(-)$ & $(-)$ & $(-)$ & $(-)$ \\
\hline
\end{tabular}

Notices: (-) Not detected with colorant; (+) detected with colorant at a concentration lower than LOQ.

It was recognized that the "positive" sample group included all types of grilled meat tested, all types of location, and almost all districts where samples were collected. For this study, the number of samples tested was not big enough to obtain statistical data or conclusions. However, the high percentage of positive results claimed a warning for public health concerning the illegal use of industrial dye in food.

Compared to another analytical method that successfully detected chrysoidine $\mathrm{G}$ in chili powder in China recently [14], all detected samples in this study were at a lower concentration than the LOQ of the method in [14]. Other methods on similar matrix-like meat [15] tuna fish [16] that would be sensitive enough for the concentration detected here were methods that used SPE columns for sample preparation. Therefore, the results obtained exhibited the feasibility of the analytical method in our study in detecting illegal colorants in the complex sample.

\section{CONCLUSION}

An LC-MS/MS method was validated for the simultaneous determination of three illegal colorants including chrysoidine G, para red, and pararosaniline in grilled meat. Validation results showed good repeatability and high accuracy with satisfactory detection limits. The chosen method was applied for the screening of the three colorants in 49 grilled meat samples of different types: grilled pork skewers, meatballs skewers, grilled pork in a big piece, doner kebab meat, and sausages. Among these samples, 19 samples were detected with chrysoidine $\mathrm{G}$ at different concentrations. Especially nine out of the 19 samples were not detected with illegal colorants in the homogenized sampling but only detected in the samples where more condensable colored parts were selected. This remark suggested a different way of sampling for the meat sample in a big whole piece, with which the homogenization was too difficult, or might become a dilution step - an obstacle for the detection of illegal colorant. The high number of samples positive with chrysoidine $\mathrm{G}$ in different types of meat, in different areas suggested that this colorant might be more commonly abused in Hanoi market these days, and further investigations on a higher number of samples with a more logical sampling map might be a good step to continue for this study. 


\section{REFERENCES}

[1]. Ministry of Health, Circular no. 24/2019/TT-BYT, Regulation on the management and use of food additives, issued on 30/08/2019.

[2]. S. Dixit, S.K. Khanna, and M. Das, "All India survey for Anlyses of Colors in Sweets and Savories: Exposure Risk in Indian population" Journal of Food Science, vol. 78, no. 4, pp. 642-647, 2013.

[3]. J.Li, X.M. Ding, D.D. Liu, F. Guo, Y.Chen, Y.B.Zhang, H.M.Liu, "Simultaneousdetermination of eight illegal dyes in chili products by LC-MS/MS", Journal of Chromatography B, vol. 942-943, pp. 46-52, 2013.

[4]. Republic of the Philippines, Food and Drug Administration, "Public Warning on the use of Industrial Grade Coloring Dyes by Food Processors", FDA Advisory on Products Positive on Rhodamine, 2013.

[5]. V. L. Phuong, N. T. H. Binh, D. T. Huyen, L. T. K. Van, T. C. Son and L. T. H. Hao, “The study simultaneously identified a number of pigments that were illegally mixed in food by double mass spectrometry liquid chromatography", Vietnamese Journal of Food Control, vol. 3, no. 1, pp. 1-10, 2020.

[6]. Y. Tonogai, S. Ogawa, Y. Ito and M. Iwaida (1982), "Actual survey on TLm (median tolerance limit) values of environmental pollutants, especially on amines, nitriles, aromatic nitrogen compounds and arti cial dyes", Journal of Toxicological Sciences, vol. 7, no. 3, pp. 193-203, 1982.

[7]. H. Sun, Y. Liu, M. Li, S. Han, X. Yang, and R. Liu, “Toxic effects of chrysoidine on human serum albumin: isothermal titration calorimetry and spectroscopic investigations", Luminescence, vol. 31, pp. 335-340, 2016.

[8]. U.S. Government Printing Office, Washington, DC, CFR, Code of Federal Regulations, Title 21, 2014.

[9]. F. Feng, Y. Zhaoa, W. Yonga, L. Suna, G. Jiang, X. Chu, "Highly sensitive and accurate screening of 40 dyes in soft drinks by LC-ESI-MS/MS", Journal of Chromatography B, vol. 879, pp. 1813-1818, 2011.

[10]. K. Suzuki, K. Mae, F. Ishikawa, Y. Sadamasu, T. Fujiwara, K. Ito, "Analysis of colors used in eggs", Annual Report of the Tokyo Metropolitan Institute for Public Health, vol. 58, pp. 163167, 2007.

[11]. R. Liu, W. Hei, P. He, Z. Li, "Simultaneous determination of fifteen illegal dyes in animal feeds and poultry products by UPLC-MS/MS", Journal of Chromatography B, vol. 879, pp. 2416-2422, 2011.

[12]. X. Zhong, T. Ohtsuki, H. Kubota, K. Sato, H. Akiyama, "A simple and rapid chromatographic method to determine unauthorized basic colorants (rhodamine $\mathrm{B}$, auramine $\mathrm{O}$, and pararosaniline) in processed foods Chiye Tatebe", Food Science and Nutrition, vol. 2, no. 5, pp. 547-556, 2014.

[13]. AOAC International, “Guidelines for Standard Method Performance Requirements”, $A O A C$ Official Methods of Analysis, USA, 2017. 
[14]. S. Zhu, D. Liu, X.Y. Zhu, A. Su, and H.X Zhang, "Extraction of Illegal Dyes from Red Chili Peppers with Cholinium-Based Deep Eutectic Solvents", Journal of Analytical Methods in Chemistry, vol. 20, pp.1-6, 2017.

[15]. H. Sun, N. Sun, H. Li, J. Zhang, and Y. Yang, "Development of Multiresidue Analysis for 21 Synthetic Colorants in Meat by Microwave-Assisted Extraction-Solid-Phase ExtractionReversed-Phase Ultrahigh Performance Liquid Chromatography", Food Analytical Methods, vol. 6, no. 5, pp. 1291-1299, 2013.

[16]. W. Gui, Y. Xu, L. Shou, G. Zhu, and Y. Ren, "Liquid chromato- graphy-tandem mass spectrometry for the determination of chrysoidine in yellow- n tuna", Food Chemistry, vol. 122, no. 4, pp. 1230-1234, 2010.

\section{Xác định một số chất màu sử dụng trái phép trong thịt nướng bằng sắc ký lởng khối phổ hai lần}

Doãn Thu Huyền ${ }^{1}$, Phạm Thị Thanh Hà ${ }^{1}$, Nguyễn Quang Hà, Lương Nguyễn Thuỳ Dương ${ }^{2}$ Trịnh Việt Văn $n^{2}$, Nguyễn Thị Hồng Ngọc ${ }^{3}$, Trần Cao Sơn ${ }^{3}$

${ }^{1}$ Truờng Đại học Dược Hà Nội

${ }^{2}$ Truiờng THPT chuyên Nguyễn Huệ, Hà Nội

${ }^{3}$ Viện Kiêm nghiệm an toàn vệ sinh thực phâm quốc gia, Hà Nội

\section{Tóm tắt}

Phương pháp sắc ký lỏng khối phổ hai lần định lượng đồng thời ba chất màu chrysoidin $\mathrm{G}$, para red và pararosanilin đã được thẩm định trên nền mẫu thịt nướng. Mẫu thịt nướng được xử lý bằng $\mathrm{QuEChERS} \mathrm{và} \mathrm{phân} \mathrm{tích} \mathrm{bằng} \mathrm{LC}-\mathrm{MS} / \mathrm{MS}$. Phương pháp có độ tuyến tính tốt trong khoảng $30,0-1.000 \mu \mathrm{g} / \mathrm{L}, 5,0-1.000 \mu \mathrm{g} / \mathrm{L}$ và $0,5-1.000 \mu \mathrm{g} / \mathrm{L}$ lần lượt cho chrysoidine $\mathrm{G}$, para red và pararosaniline. Độ lặp lại và độ đúng đạt yêu câu với độ tìm lại trong khoảng 90 - 98\% và $\mathrm{RSD} \%$ trong khoảng 5,3 - 10,7\% cho cả ba chất màu. Quy trình được ứng dụng trên 49 mẫu thịt nướng các loại thu thập từ sáu khu vực khác nhau trên địa bàn Hà Nội, trong đó có 19 mẫu thịt nướng đã được phát hiện dương tính với chrysoidine $\mathrm{G}$. Một điểm đáng lưu ý là có sáu mẫu trong số các mẫu dương tính không phát hiện được chrysoidin khi tiến hành phân tích trên mẫu đã đồng nhất, mà chỉ dương tính trên mẫu đã lựa chọn phân trên bề mặt có màu đậm hơn.

Tư khóa: Chất màu trộn trái phép, thịt nướng, sắc ký lỏng khối phổ hai lân, chrysoidine G, para red, pararosaniline. 